\title{
Biodiversity down by the flow: new records of monogonont rotifers for Italy found in the Po River
}

\author{
Isabella BERTANI, Hendrik SEGERS ${ }^{1)}$ and Giampaolo ROSSETTI \\ Department of Environmental Sciences, University of Parma, Viale G.P. Usberti 11A, I-43100 Parma, Italy \\ ${ }^{1)}$ Belgian Biodiversity Platform, Freshwater Laboratory, Royal Belgian Institute of Natural Sciences, Vautierstraat 29, B-1000 \\ Brussels \\ *e-mail of the corresponding author: isabella.bertani@nemo.unipr.it
}

\begin{abstract}
Surveys on the zooplankton of the middle reach of the Po River (Northern Italy) carried out from 2008 to 2010 led to the discovery of 24 species of monogonont rotifers that are new for Italy. Among the 17 recorded genera, six are new for the Italian fauna, while three species have never been reported in the Palaearctic Region before. Temporal patterns, abundance and site of occurrence of the species are provided. Available information on the ecology and distribution of each taxon was derived from the literature and is also reported. Most of the new records are littoral and/or benthic-periphytic taxa. Results of the present study underline the still unsatisfactory status of present biogeographical knowledge on monogonont rotifers and the need for detailed taxonomic surveys in order to improve our understanding of the ecology and distributional patterns of this group.
\end{abstract}

Key words: potamoplankton, taxonomy, biogeography, ecology

\section{INTRODUCTION}

Rotifers have long been recognised as a critical component of freshwater ecosystems, yet information on their ecology and distribution is still limited (Wallace et al. 2006). This is due to issues like inadequate taxonomic and molecular knowledge on the phylum, identification difficulties related to phenotypic plasticity and cryptic speciation as well as insufficiency of reliable biogeographical studies, especially in developing countries (Segers 2008). With approximately 1600 known species, the group Monogononta is the most diverse of rotifers (Segers 2007). Of them, only about 200 species or species-groups belonging to 46 genera in 20 families are reported in the checklist of the Italian fauna (Braioni $\&$ Ricci 1995). Sixty-five species were reported by earlier studies but not included in the aforementioned checklist (De Ridder \& Segers 1997). In addition to that, 58 more species were recorded by subsequent works (Fontaneto \& Melone 2003; Rossetti et al. 2003; Fontaneto et al. 2004; De Smet 2007; Fontaneto et al. 2008; Bertani et al. 2009; De Smet 2009; Rossetti et al. 2009).

In Italy, extensive field research has traditionally been carried out on monogonont rotifers in lentic ecosystems, while a comparatively smaller amount of studies have focused on lotic communities (e.g., Braioni 1981; Ferrari et al. 1989). Nevertheless, rotifers typically represent the dominant group in terms of abundance among metazoan plankton in large rivers, because of their fast generation times (Lair 2006). Rotifer richness is especially enhanced in high-order rivers; this is due to the influence of abiotic constraints like fluctuations in the hydrological regime, that may act as a dis- turbance factor, promoting equitability and diversity of plankton assemblages (Rossetti et al. 2009). Moreover, the hydrogeomorphic complexity of fluvial systems often provides an extremely diverse array of substrates and microhabitats that favours the development of rich benthic-periphytic assemblages (Ricci \& Balsamo 2000; Thorp et al. 2006). These latter may be subjected to dislodgement and resuspension, especially during high water phases, further enriching the truly planktonic community (Braioni 1981; Schmid-Araya 1998). Accordingly, assemblages found in the main current of rivers typically derive from a mixture of planktonic organisms and inocula from benthic and periphytic substrates, inshore retention zones, backwaters, periodically inundated floodplain habitats and tributaries. Thus, these assemblages can be considered as representative of the aquatic biodiversity of a much broader area than the main river channel. This has been shown by several studies carried out since the 1980s in the middle reach of the Po River (Northern Italy), which revealed the presence of a well developed and highly diverse rotifer assemblage (see Rossetti et al. 2009 for a comprehensive account of the extant studies on the Po River zooplankton).

We report 24 species of monogonont rotifers new to Italy (i.e. not included in the checklist compiled by Braioni \& Ricci 1995) that have been found during further surveys conducted in recent years in the potamal stretch of the Po River.

\section{MATERIALS AND METHODS}

Two sampling campaigns were carried out to study the zooplankton community of the middle reach of the 
Tab. 1. Taxonomic account and global distribution (Afr: Afrotropical region; Ant: Antarctic region; Aus: Australian region; Nea: Nearctic region; Neo: Neotropical region; Ori: Oriental region; Pac: Pacific region; Pal: Palaearctic region) of the rotifer taxa reported in this study (according to Segers, 2007). Asterisks indicate new records for the Palaearctic region.

\begin{tabular}{|c|c|c|}
\hline Family & Species & Distribution \\
\hline Brachionidae & Brachionus durgae Dhanapathi, 1974 & Afr, Neo, Ori, Pal \\
\hline Epiphanidae & Rhinoglena frontalis Ehrenberg, 1853 & Ant, Aus, Nea, Ori, Pal \\
\hline Lecanidae & $\begin{array}{l}\text { Lecane elegans Harring, } 1914 \\
\text { Lecane fadeevi (Neiswestnova-Shadina, 1935) } \\
\text { Lecane hastata (Murray, 1913) } \\
\text { Lecane pyriformis (Daday, 1905) }\end{array}$ & $\begin{array}{l}\text { Afr, Neo, Ori, Pac, Pal } \\
\text { Pal } \\
\text { Afr, Aus, Nea, Neo, Ori, Pac, Pal } \\
\text { Afr, Aus, Nea, Neo, Ori, Pac, Pal }\end{array}$ \\
\hline Lepadellidae & $\begin{array}{l}\text { Lepadella (Xenolepadella) astacicola Hauer, } 1926 \\
\text { Lepadella (Lepadella) biloba Hauer, } 1958\end{array}$ & $\begin{array}{l}\text { Neo, Pal } \\
\text { Afr, Aus, Neo, Pal }\end{array}$ \\
\hline Notommatidae & $\begin{array}{l}\text { *Cephalodella } \text { cfr. hollowdayi Koste, } 1986 \\
\text { Cephalodella theodora Koch-Althaus, } 1961 \\
\text { Cephalodella trigona (Rousselet, 1895) } \\
\text { Enteroplea lacustris Ehrenberg, } 1830 \\
\text { Eosphora anthadis Harring \& Myers, } 1922 \\
\text { Notommata cyrtopus cyrtopus Gosse, } 1886 \\
\text { * Resticula anceps Harring \& Myers, } 1924\end{array}$ & $\begin{array}{l}\text { Neo } \\
\text { Nea, Pal } \\
\text { Pal } \\
\text { Aus, Nea, Neo, Ori, Pal } \\
\text { Aus, Nea, Neo, Ori, Pal } \\
\text { Afr, Ant, Aus, Nea, Neo, Ori, Pac, Pal } \\
\text { Nea }\end{array}$ \\
\hline Dicranophoridae & $\begin{array}{l}\text { Aspelta circinator (Gosse, 1886) } \\
\text { Dicranophorus luetkeni (Bergendal, 1892) } \\
\text { Encentrum wiszniewskii Wulfert, 1939 } \\
\text { Kostea wockei (Koste, 1961) } \\
\text { Paradicranophorus hudsoni (Glascott, 1893) } \\
\text { Parencentrum lutetiae (Harring \& Myers, 1928) }\end{array}$ & $\begin{array}{l}\text { Aus, Nea, Neo, Pal } \\
\text { Afr, Aus, Nea, Neo, Ori, Pal } \\
\text { Pal } \\
\text { Afr, Neo, Pal } \\
\text { Aus, Pal } \\
\text { Ori, Pal }\end{array}$ \\
\hline Trichocercidae & $\begin{array}{l}\text { *Trichocerca braziliensis (Murray, 1913) } \\
\text { Trichocerca tenuior (Gosse, 1886) }\end{array}$ & $\begin{array}{l}\text { Afr, Aus, Neo, Ori, } \\
\text { Afr, Aus, Nea, Neo, Ori, Pac, Pal }\end{array}$ \\
\hline Trichotriidae & Wolga spinifera (Western, 1894) & Afr, Aus, Nea, Neo, Ori, Pal \\
\hline
\end{tabular}

Po River, which is the main watercourse in Italy both in terms of length $(650 \mathrm{~km})$ and catchment surface $(70700$ $\mathrm{km}^{2}$ ). Zooplankton samples were collected fortnightly between February 2008 and April 2010 at a station close to the town of Viadana $\left(44^{\circ} 18^{\prime} \mathrm{N}, 10^{\circ} 22^{\prime} \mathrm{E}\right)$. An additional fortnightly survey was conducted from June to September 2009 at three stations respectively upstream, inside and downstream of the artificial impoundment of Isola Serafini, located about $60 \mathrm{~km}$ upstream of Viadana. At the station of Viadana, samples were taken from a floating pontoon that enabled to reach the main current flow in the river, while at the Isola Serafini stations sampling was carried out from a boat in the middle of the channel. In both cases, a 15-L bucket was thrown into the river, so that only the uppermost layers of the water column could be sampled. Water was then passed through a $50 \mu \mathrm{m}$ net until 60-90 L were filtered. Preservation in $4 \%$ buffered formalin followed immediately. While this may complicate identification of illoricate rotifer species, the resulting contraction is required to enable correct diagnosis of loricate rotifers. Identification of illoricate contracted specimens is in most cases possible by examining elements of body morphology and anatomy, and of trophi. Trophi were extracted by adding a solution of sodium hypochlorite to dissolve the soft tissues.

For species identification the following references were used: Koste (1978), Segers (1994; 1995), Segers et al. (1994), Nogrady et al. (1995), De Smet \& Pourriot (1997), De Smet \& Gibson (2008).

\section{RESULTS AND DISCUSSION}

A total of 139 rotifer taxa were found in the Po River, 24 of which represent new records for the Italian fauna (Tab. 1). Six genera (Aspelta, Enteroplea, Kostea, Paradicranophorus, Parencentrum and Wolga) are not included in the latest version of the checklist of the Italian fauna (Braioni \& Ricci 1995) and three species are new records for the Palaearctic Region (Segers 2007; Tab. 1). A summary on the ecology of each species based on the available literature is given below. Most of the records refer to a single or a limited number of specimens occasionally found in plankton samples. Information on temporal patterns, abundance and site of occurrence of each species is provided in table 2 and figure 3.

\section{Brachionus durgae Dhanapathi, 1974 (Fig. 1A)}

Brachionus durgae was originally described from India (Dhanapathi 1974). A redescription of the taxon, together with updated information on its distribution, was provided by Segers et al. (1994). It was typically found during summer low-flow conditions in the Po River, although with very modest abundances (maxima of 800 and 900 ind $\mathrm{m}^{-3}$ were recorded in August 2009 at Isola Serafini and Viadana, respectively). We also found the species in samples previously collected in the same river reach (summer 2005; unpublished data); thus, we suggest that $B$. durgae has been present in the Po River for many years and was probably con- 
Tab. 2. Occurrence of rotifer taxa in the Po River. Unless otherwise specified (see notes below), data are referring to the station of Viadana. Symbols indicate abundances as follows: $\leq 200$ ind $\mathrm{m}^{-3} ; \bullet 200-500 \mathrm{ind}^{-3} ; \bullet>500$ ind $\mathrm{m}^{-3}$. In cases where a species was found in more than one sampling date in the same month, the highest recorded abundance is reported. For the occurrence of Lecane fadeevi see text and Fig. 3. (1): the record of July 2009 refers to Isola Serafini; in August 2009 the species was found with similar abundances (see text) at both Viadana and Isola Serafini stations. (2): the record refers to Isola Serafini. (3): the record of August 2009 refers to Isola Serafini.

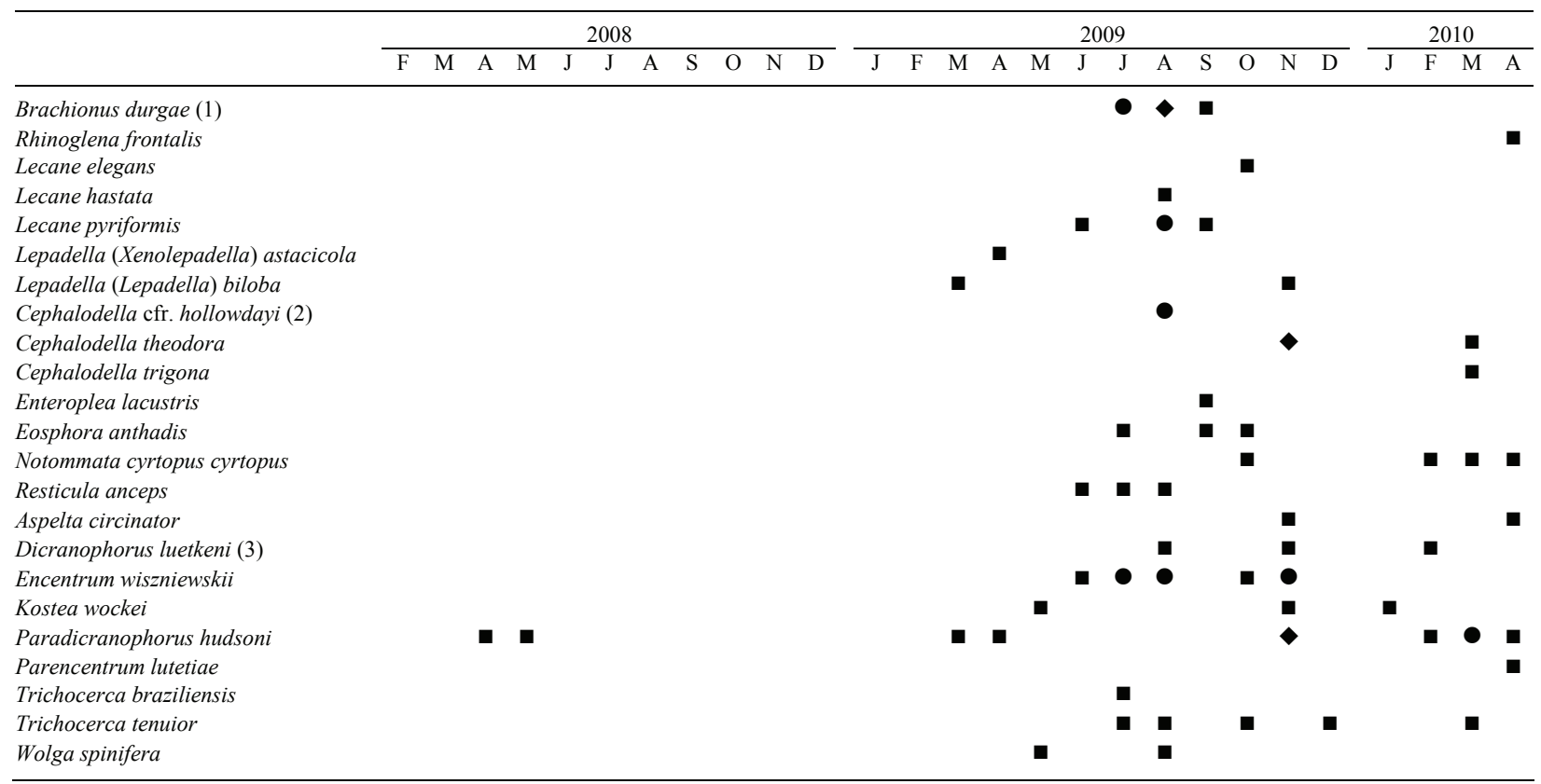

fused with similar congenerics in previous surveys. This species has been reported from lakes, permanent and temporary ponds (Segers et al. 1994).

\section{Rhinoglena frontalis Ehrenberg, 1853}

The genus Rhinoglena comprises four described species (De Smet \& Gibson 2008). Among them, only $R$. tokioensis has been recorded in Italy so far, in a small wetland in the Po River floodplain (Rossetti et al. 2003). Rhinoglena frontalis is a cold stenotherm and widespread species (Koste 1978; De Smet \& Gibson 2008) that typically inhabits small, shallow ponds and temporary floodplain habitats (Schröder 2005 and refs. therein). It is described as exclusively phytophagous, feeding mainly on unicellular algae (Koste 1978; Pourriot 1977) and showing rather slow swimming movements (Ruttner-Kolisko 1974; Koste 1978).

\section{Lecane elegans Harring, 1914 (Fig. 1B)}

Published data on the ecology of this species are lacking. It is reported in rivers (e.g., Koste 1978; Wang et al. 2009) and floodplain habitats (e.g., Sanoamuang 1998; Serafim et al. 2003).

\section{Lecane fadeevi (Neiswestnowa-Shadina, 1935) (Fig. 1C)}

Lecane fadeevi was found at the sampling sites of both Viadana (see Fig. 3) and Isola Serafini. In the latter case, a maximum of 2833 ind $\mathrm{m}^{-3}$ was recorded in July 2009 , while in the rest of the sampling dates abundances never exceeded 1250 ind $\mathrm{m}^{-3}$.
The record of L. fadeevi is of particular interest because it has previously been reported only from two rivers in the Moscow Region (Russia) and one in Poland, where it was found living in the interstitial of sandy sediments or among the shore vegetation (Segers 1994 and refs. therein). The lorica and head aperture shape is very similar to that of its close relative $L$. closterocerca. Nevertheless, they can be distinguished by the toe shape, bulging medially in L. fadeevi, parallelsided and tapering to a sharp, spiniform tip in L. closterocerca (Segers 1994, 1996). This similarity to the cosmopolitan L. closterocerca is probably the reason why $L$. fadeevi has not been reported from previous surveys in the Po River. In fact, a re-examination of samples collected during summer 2005 in the same river trait revealed the overlooked presence of the species (unpublished data).

Previous records from Central and Eastern European rivers report the co-occurrence of the two closely related species (Segers 1994). During our survey at Viadana both species were present too, but they exhibited asynchronous fluctuations in population abundance. In fact, a similar pattern was observed in 2008 and 2009, with the peaks of $L$. closterocerca always immediately following the decline of $L$. fadeevi (see Fig. 3).

Lecane hastata (Murray, 1913) (Fig. 1D)

Lecane hastata is described in the literature as a cosmopolitan species that can be found in the periphyton and psammon of both brackish and freshwater habitats (Koste 1978; Segers 1995; Turner 1996). 


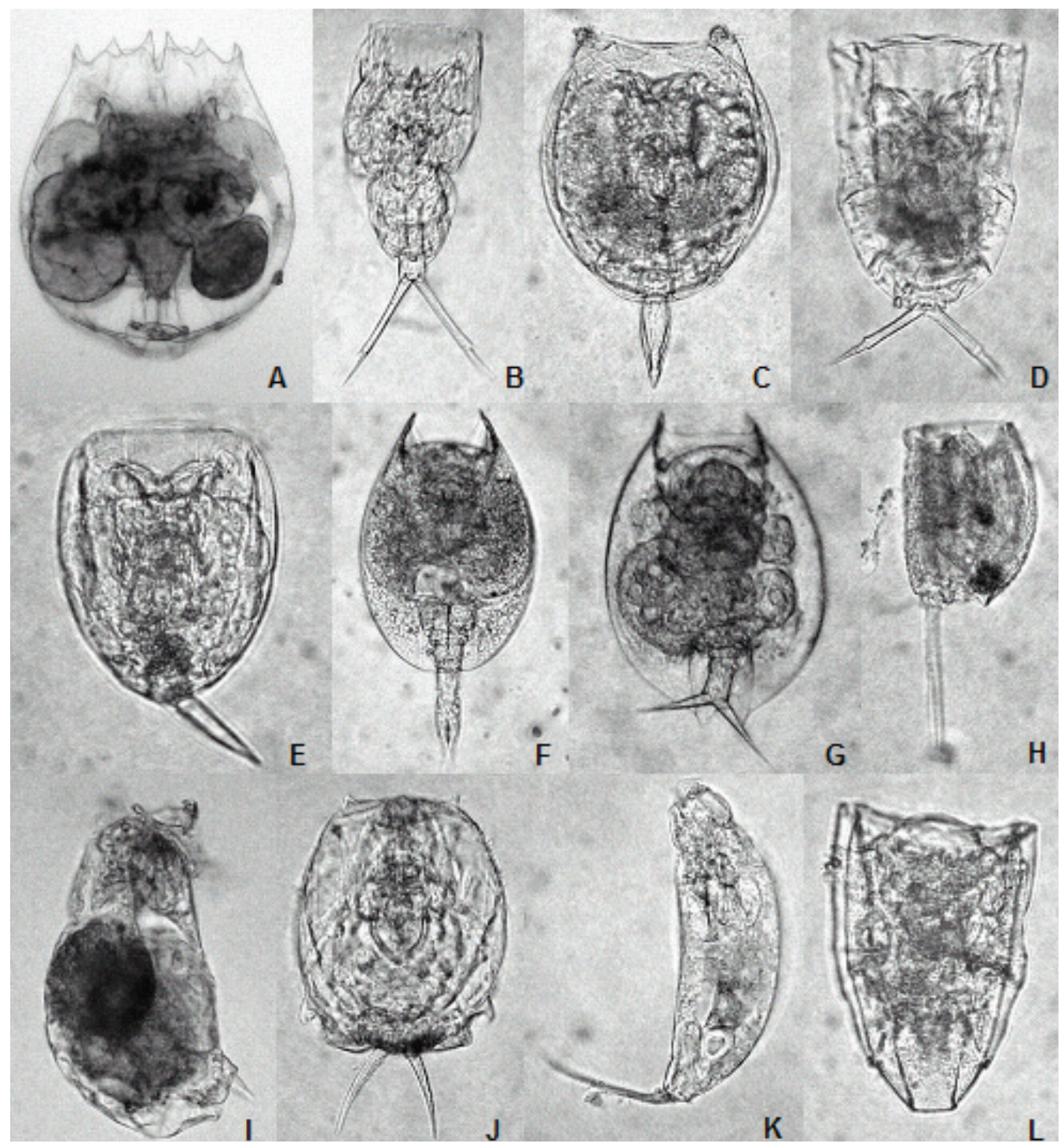

Fig. 1. Microphotographs (not to scale) of rotifer species found in this study. Some soft-bodied specimens are contracted due to formalin fixation. A: Brachionus durgae; B: Lecane elegans; C: Lecane fadeevi; D: Lecane hastata; E: Lecane pyriformis; F: Lepadella (Xenolepadella) astacicola; G: Lepadella (Lepadella) biloba; H: Cephalodella trigona; I: Encentrum wiszniewskii; J: Kostea wockei; K: Trichocerca tenuior; L: Wolga spinifera.

Lecane pyriformis (Daday, 1905) (Fig. 1E)

Lecane pyriformis is a cosmopolitan littoral rotifer that generally lives in the periphyton of standing and running waters (Koste 1978; Segers 1995). It is also reported from slightly to highly saline water bodies (Walsh et al. 2008; Kaya et al. 2010).

\section{Lepadella (Xenolepadella) astacicola Hauer, 1926 (Fig. 1F)}

Despite being reported as living in the branchial cavities of freshwater crayfish such as Astacus fluviatilis, A. leptodactylus and Cambarus affinis (Koste 1978), this species has also been found in plankton samples of both standing and running waters (EjsmontKarabin \& Kruk 1998; Sarma \& Elías-Gutiérrez 1999; De Manuel 2000).
Lepadella (Lepadella) biloba Hauer, 1958 (Fig. 1G)

This cosmopolitan taxon was originally considered a subspecies of $L$. patella, but later elevated to the species rank by Segers \& De Meester (1994). It commonly inhabits the littoral of ponds, like the majority of its congeners; the genus Lepadella comprises in fact mainly benthic-periphytic forms, occasionally to be found in plankton but often present in the drift of running waters (Koste 1978; Pejler \& Bērziñš 1993).

\section{Cephalodella cfr. hollowdayi Koste, 1986 (Fig. 2A)}

Originally described from the floodplain of Rio Paraguay (Koste 1986), to our knowledge this is the first record of the taxon outside the Neotropical Region (Segers 2007). It is reported from both lentic and lotic 


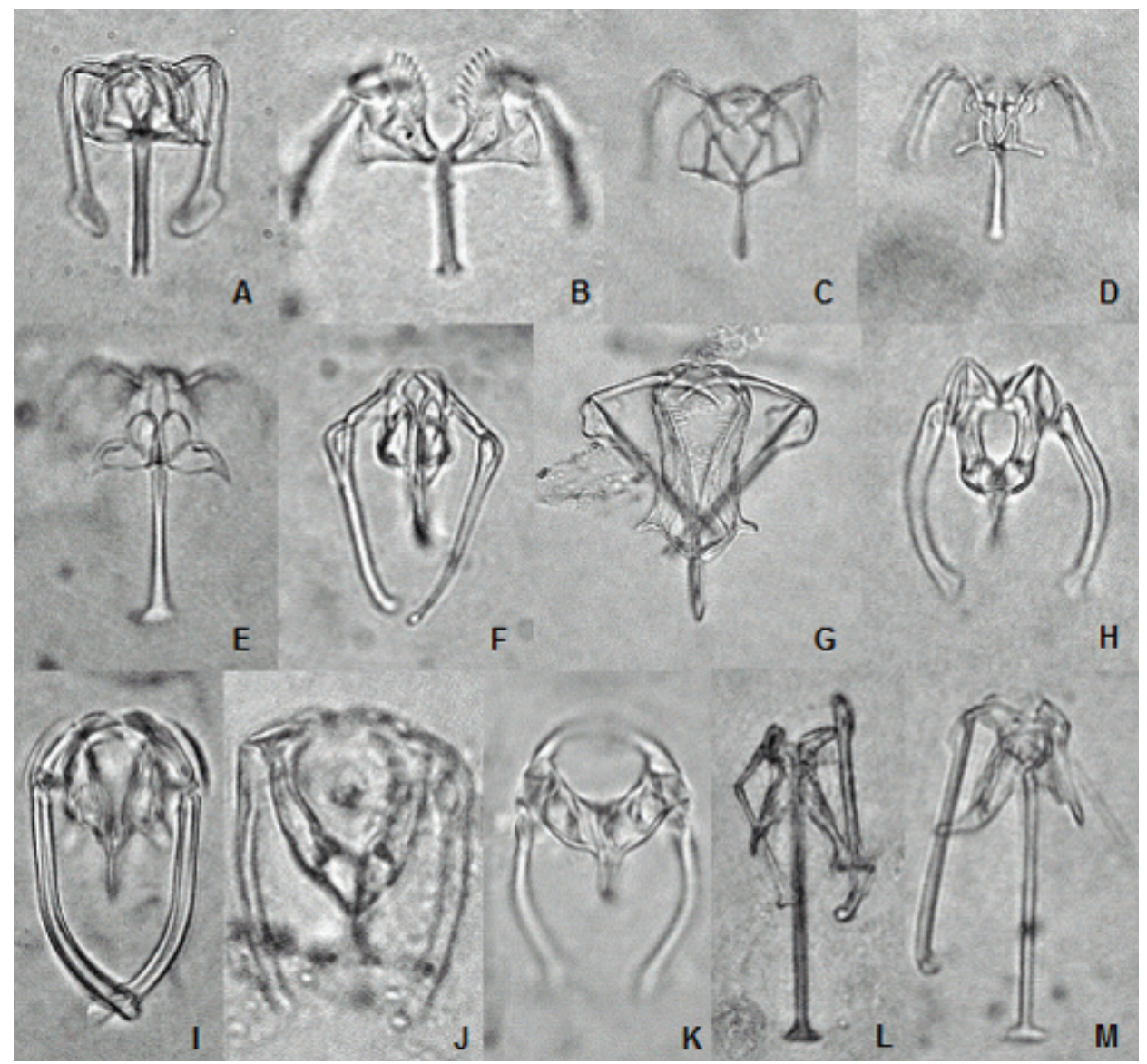

Fig. 2. Microphotographs of trophi (not to scale) belonging to rotifer species found in this study. A: Cephalodella cfr. hollowdayi; B: Cephalodella theodora; C: Enteroplea lacustris; D: Eosphora anthadis; E: Resticula anceps; F: Aspelta circinator; G: Dicranophorus luetkeni; H: Encentrum wiszniewskii; I: Kostea wockei; J: Paradicranophorus hudsoni; K: Parencentrum lutetiae; L: Trichocerca braziliensis; M: Trichocerca tenuior.

water bodies (Nogrady et al. 1995; Keppeler \& Hardy 2004; Janetzky et al. 1995).

Cephalodella theodora Koch-Althaus, 1961 (Fig. 2B)

Cephalodella theodora has been found in both backwaters and main channels of streams and rivers (Zsuga 1997; Bjørklund 2009). It is a rare benthic-periphytic rotifer, usually inhabiting the littoral of water bodies, especially among macrophytes and algal mats (Jersabek \& Bolortsetseg 2010).

\section{Cephalodella trigona (Rousselet, 1895) (Fig. 1H)}

Bērziñš (1954) reported the presence of C. trigona in Southern Italy, but his record was omitted by Braioni \& Ricci (1995). Having a heavier lorica than most Cephalodella species and dorsal keels, the habitus of $C$. trigona may appear similar to that of a Mytilina. Nonetheless, the granulated lorica and especially the virgate trophi (malleate in Mytilina) are diagnostic features of the genus and species (Nogrady et al. 1995). Sparse information is available on the ecology of this taxon, which is described as inhabiting small ephemeral ponds (Nogrady et al. 1995).
Enteroplea lacustris Ehrenberg, 1830 (Fig. 2C)

Although previously recorded from Italy by Mola (1931) and Taticchi (1968), this species is not included in the checklist of the Italian fauna (Braioni \& Ricci, 1995). This could be due to the fact that such records are questionable. This is especially the case for those by Mola (1931), whose rotifer descriptions are of a quality that does not enable recognition of the taxon recorded (see list of "species inquirendae" in Segers 1995). Enteroplea lacustris is the only species known for this genus (Segers 2007). It is described in the literature as cosmopolitan but rare, typically found in shallow or ephemeral ponds (Nogrady et al. 1995). It is a predatory rotifer feeding on bdelloids, as observed both in laboratory cultures (Pourriot 1965) and field populations (José de Paggi 2001).

Eosphora anthadis Harring \& Myers, 1922 (Fig. 2D)

Among the seven species of this genus (Segers 2007), only E. najas and E. ehrenbergi have so far been recorded from Italy (Taticchi 1968; Bērzinšs 1978; Fontaneto \& Melone 2003). Eosphora anthadis is a cosmo- 


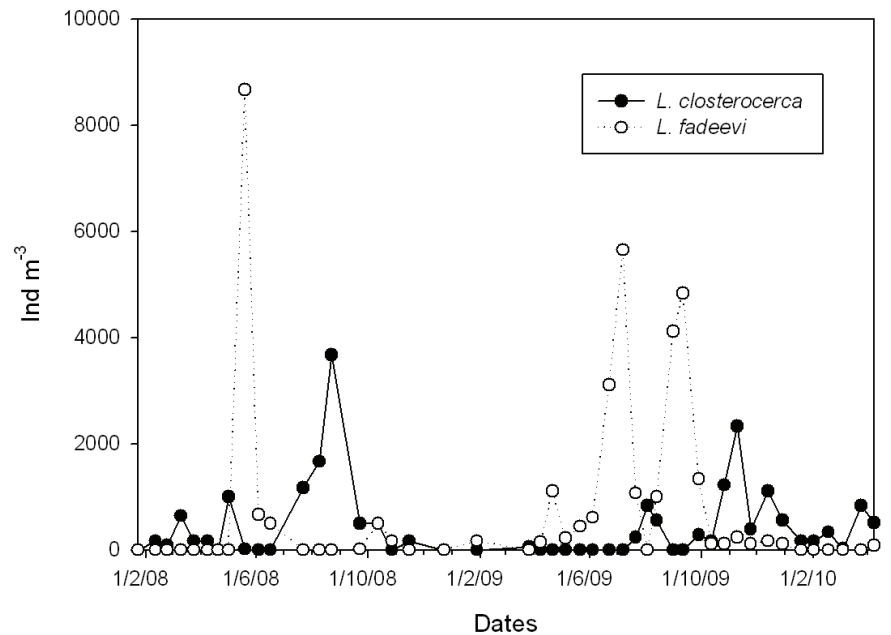

Fig. 3. Abundances of Lecane closterocerca and Lecane fadeevi recorded between February 2008 and April 2010 at the station of Viadana.

politan but rare predatory rotifer, which was observed preying upon peritrich ciliates (Kusuoka \& Watanabe 1989; Nogrady et al. 1995).

\section{Notommata cyrtopus cyrtopus Gosse, 1886}

The first record of $N$. cyrtopus for the Italian fauna dates back to the work of Mola (1930), but the species is not listed by Braioni \& Ricci (1995), possibly for the same reason as for his record of E. lacustris. It is a cosmopolitan rotifer, common in the periphyton and littoral of both standing and running waters (Koste 1978; Nogrady et al. 1995).

Resticula anceps Harring \& Myers, 1924 (Fig. 2E)

The genus Resticula comprises seven known species (Segers 2007), of which only $R$. gelida and $R$. nyssa have been found in Italy so far (Braioni \& Ricci 1995; Bertani et al. 2009). No information is available on the ecology of $R$. anceps; it is a rare species that to our knowledge has previously been reported only from the Nearctic Region (Segers 2007).

Aspelta circinator (Gosse, 1886) (Fig. 2F)

Despite the record of Aspelta aper by Bērziñš in Italy (1978), the genus Aspelta is not listed by Braioni \& Ricci (1995). Aspelta circinator is a widespread taxon, although sporadic (De Smet \& Pourriot 1997). It lives in the mud over different substrates such as mosses; it is present also in acidic waters (Koste 1978), among submerged vegetation and in the littoral psammon of lakes and rivers (De Smet \& Pourriot 1997; Jersabek \& Bolortsetseg 2010). Like the majority of its congeners, it is carnivorous and feeds on other rotifers, ciliates and nematodes (De Smet \& Pourriot 1997).

Dicranophorus luetkeni (Bergendal, 1892) (Fig. 2G)

This cosmopolitan rotifer is commonly found in the littoral of both lotic and lentic water bodies, especially in the periphyton and psammon, among macrophytes and in the interstitial of streams (De Smet \& Pourriot 1997; Jersabek \& Bolortsetseg 2010). It feeds on diatoms and other rotifers (Jersabek 1998).

Encentrum wiszniewskii Wulfert, 1939 (Figs 1I and 2H)

Sporadic individuals of E. wiszniewskii were found in samples collected at Viadana throughout the summer and autumn 2009. It is reported in the literature as a typical inhabitant of the river psammon (Turner 1996; De Smet \& Pourriot 1997).

Kostea wockei (Koste, 1961) (Figs 1J and 2I)

The genus Kostea was specifically established by De Smet (1997) to contain the species formerly designated as Paradicranophorus wockei. Kostea wockei is reported as a littoral rotifer, often inhabiting sandy and muddy sediments of both standing and running waters. It feeds on small rotifers and nematodes as well as on algae (Koste 1978; De Smet 1997).

\section{Paradicranophorus hudsoni (Glascott, 1893) (Fig. 2J)}

The genus Paradicranophorus includes six known species (Segers 2007). Sparse individuals of $P$. hudsoni were found in spring of each year (Tab. 2), but in November 2009 an isolated peak of 1926 ind $\mathrm{m}^{-3}$ was observed. This cosmopolitan rotifer lives both in freshwater and marine habitats and although it can occasionally be found in plankton or in the drift of running waters, it is a littoral species typically associated with muddy bottoms and shores (Koste 1978; De Smet \& Pourriot 1997).

Parencentrum lutetiae (Harring \& Myers, 1928) (Fig. 2K)

Only two known species belong to the genus Parencentrum (Segers 2007). Parencentrum lutetiae can be found in muddy sediments of both lentic and running waters (De Smet \& Pourriot 1997). Information on its ecology and distribution is scarce. Outside of Europe it 
has been recorded only in Laos (Segers \& Sanoamuang 2007).

\section{Trichocerca braziliensis (Murray, 1913) (Fig. 2L)}

This is the first record of $T$. braziliensis for the Palaearctic Region, even though confusion with the similar $T$. rattus might have led to an underestimation of its actual distribution in temperate regions (Segers \& De Meester 1994). Trichocerca braziliensis seems to prefer warm waters and so far it has mainly been reported from tropical and subtropical regions, where it is relatively widespread (Segers \& De Meester 1994; Segers 2003).

\section{Trichocerca tenuior (Gosse, 1886) (Figs 1K and 2M)}

Despite being a cosmopolitan taxon (Segers 2003), to our knowledge this is the first record of T. tenuior for Italy (Braioni \& Ricci 1995). Like most of the species belonging to this genus, $T$. tenuior typically lives in detritus, periphyton and psammon of standing waters as well as in the littoral of streams, occurring only occasionally in open water habitats; it is also found in bogs (Koste 1978).

\section{Wolga spinifera (Western, 1894) (Fig. 1L)}

Wolga spinifera, the only species of the genus Wolga according to Segers (2007), has been recorded from Sicily (Southern Italy) by Bērziņš (1954), although it is not included in the checklist of the Italian fauna (Braioni \& Ricci 1995). It is a widespread benthic-periphytic rotifer that is commonly found among macrophytes and on muddy sediments in lentic water bodies, rice fields, streams and rivers (Koste 1978; Jersabek \& Bolortsetseg 2010).

\section{CONCLUSIONS}

Most of the recorded species are reported in the literature as littoral and/or benthic-periphytic. This probably explains why they occurred only sporadically in plankton samples collected in the main river channel. Nevertheless, their finding supports the notion of large lowland rivers and their floodplain as capable of sustaining extremely rich and diverse rotifer assemblages (Segers et al. 1993; Lair 2006) and the need to investigate all types of heterogeneous environments, substrates and microhabitats that contribute to the overall biodiversity of riverine ecosystems (Ward \& Tockner 2000).

The record of species previously reported only from other biogeographical regions once again emphasizes how substantial gaps still affect our understanding of rotifer species' chorology. Taxa that are considered rare or endemic of certain areas might be much more widespread than currently assumed.

To sum up, our work is a contribution to the present knowledge on the distribution of monogonont rotifers and indicates that much remains to be done to get a reliable picture on the biogeography and ecology of this group.

\section{ACKNOWLEDGEMENTS}

The authors thank Ireneo Ferrari and Pierluigi Viaroli for their valuable suggestions. Michele Zatti and Maria Teresa Anzalone helped with the sampling and the rotifer identification. Diego Fontaneto provided useful information on the distribution of rotifers in Italy. Three referees are gratefully acknowledged for their comments which improved the manuscript.

\section{REFERENCES}

Bertani, I., H. Segers \& G. Rossetti. 2009. Monogonont rotifers (Rotifera: Monogononta) from Northern Apennine lakes: new and rare taxa for Italy. Studi Trent. Sci. Nat., Acta Biol., 86: 71-74.

Bērziņš, B. 1954. Zur Rotatorienfauna Siziliens. Hydrobiologia, 6: 309-320.

Bērziňš, B. 1978. Rotatoria. In: Illies, J. (Ed.), Limnofauna Europaea. Gustav Fischer Verlag - Stuttgart, New York; Swets and Zeitlinger B.V., Amsterdam: 54-91.

Bjørklund, B.G. 2009. Freshwater rotifers from Hordaland, western Norway, with a survey of freshwater rotifers previously found in Norway. Fauna Norveg., 29: 11-54.

Braioni, M.G. 1981. The drift of Rotifers in the River Adige: preliminary communication. Boll. Zool., 48: 305-310.

Braioni, M.G. \& C. Ricci. 1995. Rotifera. In: Minelli, A., S. Ruffo \& S. La Posta (Eds), Checklist delle specie della fauna italiana, 8. Calderini, Bologna: 1-11.

De Manuel, J. 2000. The Rotifers of Spanish reservoirs: ecological, systematical and zoogeographical remarks. Limnetica, 19: 91-167.

De Ridder, M. \& H. Segers. 1997. Rotifera Monogononta in six zoogeographical regions after publications between 1960 and 1992. In: Van Goethem, J. (Ed.), Studiedocumenten Kon. Belg. Inst. Natuurwet., 88: 481 pp.

De Smet, W.H. 2009. A review of the marine and brackishwater species of Testudinella (Rotifera: Monogononta, Testudinellidae), with the description of two new species. Zootaxa, 2092: 1-20.

De Smet, W.H. \& J.A.E. Gibson. 2008. Rhinoglena kutikovae n.sp. (Rotifera: Monogononta: Epiphanidae) from the Bunger Hills, East Antarctica: a probable relict species that survived Quaternary glaciations on the continent. Polar Biol., 31: 595-603.

De Smet, W.H. \& R. Pourriot. 1997. Rotifera. Vol. 5: The Dicranophoridae (Monogononta). SPB Academic Publishing, Amsterdam: 325 pp.

Dhanapathi, M.V.S.S.S. 1974. Rotifers from Andhra Pradesh, India - I. Hydrobiologia, 45: 357-352.

Ejsmont-Karabin, J. \& M. Kruk. 1998. Effects of contrasting land use on free-swimming rotifer communities of streams in Masurian Lake District, Poland. Hydrobiologia, 387388: 241-249.

Ferrari, I., A. Farabegoli \& R. Mazzoni. 1989. Abundance and diversity of planktonic rotifers in the Po River. Hydrobiologia, 186-187: 201-208.

Fontaneto, D. \& G. Melone. 2003. On some rotifers new for the Italian fauna. Ital. J. Zool., 70: 253-259.

Fontaneto, D., H. Segers \& G. Melone. 2004. Epizoic rotifers (Rotifera: Monogononta, Bdelloidea) from the gill chambers of Potamon fluviatile (Herbst, 1785). J. Nat. Hist., 38: 1225-1232.

Fontaneto, D., H. Segers \& G. Melone. 2008. Marine rotifers from the Northern Adriatic Sea, with description of Lecane insulaconae sp. nov. (Rotifera: Monogononta: Lecanidae). J. Mar. Biol. Assoc. U.K., 88: 253-258.

Janetzky, W., W. Koste \& E. Vareschi. 1995. Rotifers (Rotifera) of Jamaican inland waters. A synopsis. Ecotropica, 1: $31-40$. 
Jersabek, C.D. 1998. Dicranophoridae (Rotifera) from the Alps. Hydrobiologia, 387-388: 63-77.

Jersabek, C.D. \& E. Bolortsetseg. 2010. Mongolian rotifers (Rotifera, Monogononta) - a checklist with annotations on global distribution and autecology. P. Acad. Nat. Sci. Phila., 159: 119-168.

José de Paggi, S. 2001. Diversity of Rotifera (Monogononta) in wetlands of Río Pilcomayo National Park, Ramsar Site (Formosa, Argentina). Hydrobiologia, 462: 25-34.

Kaya, M., D. Fontaneto, H. Segers \& A. Altindag. 2010. Temperature and salinity as interacting drivers of species richness of planktonic rotifers in Turkish continental waters. $J$. Limnol., 69: 297-304.

Keppeler, E.C. \& E.R. Hardy. 2004. Abundance and composition of Rotifera in an abandoned meander lake (Lago Amapá) in Rio Branco, Acre, Brazil. Rev. Bras. Zool., 21 : 233-241.

Koste, W. 1978. Rotatoria. Gebrüder Borntraeger - Berlin: $673 \mathrm{pp}$.

Koste, W. 1986. Über die Rotatorienfauna in Gewässern südöstlich von Concepción, Paraguay, Südamerika. Osnabr. Naturwiss. Mitt., 12: 129-155.

Kusuoka, Y. \& Y. Watanabe. 1989. Distinction of emigration by telotroch formation and death by predation in peritrich ciliates: SEM observations on the remaining stalk ends. FEMS Microbiol. Lett., 62: 7-12.

Lair, N. 2006. A review of regulation mechanisms of metazoan plankton in riverine ecosystems: aquatic habitat versus biota. River Res. Appl., 22: 567-593.

Mola, P. 1930. Fauna rotatoria italiana delle acque dolci. Int. Rev. ges. Hydrobiol. Hydrog., 23: 428-477.

Mola, P. 1931. Addenda ed alcune errata-corrige alla "Fauna rotatoria italiana delle acque dolci". Int. Rev. ges. Hydrobiol. Hydrog., 26: 143-162.

Nogrady, T., R. Pourriot \& H. Segers. 1995. Rotifera. Vol. 3: The Notommatidae and The Scaridiidae. SPB Academic Publishing, Amsterdam: 248 pp.

Pejler, B. \& B. Bērziňš. 1993. On the ecology of Colurellidae (Rotifera). Hydrobiologia, 263: 61-64.

Pourriot, R. 1965. Recherches sur l'ecologie des rotifères. Vie Milieu, 21(suppl.): 1-224.

Pourriot, R. 1977. Food and feeding habits of Rotifera. Arch. Hydrobiol., 8: 243-260.

Ricci, C. \& M. Balsamo. 2000. The biology and ecology of lotic rotifers and gastrotrichs. Freshwat. Biol., 44: 15-28.

Rossetti, G., F. Tireni, S. Viglioli \& I. Ferrari. 2003. Ricerche ecologiche in un ambiente acquatico della golena del Po nei pressi di Casalmaggiore. Studi Trent. Sci. Nat., Acta Biol., 80: 193-200.

Rossetti, G., P. Viaroli \& I. Ferrari. 2009. Role of abiotic and biotic factors in structuring the metazoan plankton community in a lowland river. River Res. Appl., 25: 814-835.

Ruttner-Kolisko, A. 1974. Planktonic Rotifers: biology and taxonomy. Die Binnengewässer (Suppl.), 26: 1-146.

Sanoamuang, L-o. 1998. Rotifera of some freshwater habitats in the floodplain of the River Nan, northern Thailand. Hydrobiologia, 387-388: 27-33.

Sarma, S.S.S. \& M. Elías-Gutiérrez. 1999. Rotifers (Rotifera) from four natural water bodies of Central Mexico. Limnologica, 29: 475-483.

Schmid-Araya, J.M. 1998. Rotifers in interstitial sediments. Hydrobiologia, 387-388: 231-240.

Schröder, T. 2005. Diapause in monogonont rotifers. Hydrobiologia, 546: 291-306.
Segers, H. 1994. Redescription of Lecane fadeevi (Neiswestnowa-Shadina, 1935) (Rotifera, Lecanidae). Bull. Konink. Belg. Inst. Natuur. - Biol., 64: 235-238.

Segers, H. 1995. Rotifera. Vol. 2: The Lecanidae (Monogononta). SPB Academic Publishing - Amsterdam: 226 pp.

Segers, H. 1996. The biogeography of littoral Lecane Rotifera. Hydrobiologia, 323: 169-197.

Segers, H. 2003. A biogeographical analysis of rotifers of the genus Trichocerca Lamarck, 1801 (Trichocercidae, Monogononta, Rotifera), with notes on taxonomy. Hydrobiologia, 500: 103-114.

Segers, H. 2007. Annotated checklist of the rotifers (Phylum Rotifera), with notes on nomenclature, taxonomy and distribution. Zootaxa, 1564: 1-104.

Segers, H. 2008. Global diversity of rotifers (Rotifera) in freshwater. Hydrobiologia, 595: 49-59.

Segers, H. \& L. De Meester. 1994. Rotifera of Papua New Guinea, with a description of a new Scaridium Ehrenberg, 1830. Arch. Hydrobiol., 131: 111-125.

Segers, H. \& L-o. Sanoamuang. 2007. Note on a highly diverse rotifer assemblage (Rotifera: Monogononta) in a Laotian rice paddy and adjacent pond. Int. Rev. Hydrobiol., 92: 640-646.

Segers, H., C.S. Nwadiaro \& H.J. Dumont. 1993. Rotifera of some lakes in the floodplain of the River Niger (Imo State, Nigeria) II. Faunal composition and diversity. Hydrobiologia, 250: 63-71.

Segers, H., S.S.S. Sarma, S.I. Ovie \& D.K. Mbogo. 1994. Note on the taxonomy and distribution of Brachionus durgae Dhanapathi, 1974 (Rotifera: Brachionidae). J. Afr. Zool., 108: 397-400.

Serafim, M.Jr., C.C. Bonecker, D.C. Rossa, F.A. Lansac-Tôha \& C.L. Costa. 2003. Rotifers of the Upper Paraná River floodplain: additions to the checklist. Braz. J. Biol., 63(2): 207-212.

Taticchi, M.I. 1968. Vicende stagionali delle comunità litoranee del Lago Trasimeno (1963-1965). Riv. Idrobiol., 7: 195-302.

Thorp, J.H., M.C. Thoms \& M.D. Delong. 2006. The riverine ecosystem synthesis: biocomplexity in river networks across space and time. River Res. Appl., 22: 123-147.

Turner, P.N. 1996. Preliminary data on rotifers in the interstitial of the Ninnescah river, Kansas, USA. Hydrobiologia, 319: $179-184$.

Wallace, L.R., T.W. Snell, C. Ricci \& T. Nogrady. 2006. Rotifera. Vol. 1: Biology, Ecology and Systematics ( $2^{\text {nd }}$ ed.). Backhuys Publishers - Leiden: 299 pp.

Walsh, E.J., T. Schröder, R.L. Wallace, J.V. Ríos-Arana \& R. Rico-Martínez. 2008. Rotifers from selected inland saline waters in the Chihuahuan Desert of México. Saline Syst., 4: $1-11$.

Wang, Q.,Y. Yang \& J. Chen. 2009. Impact of environment on the spatio-temporal distribution of rotifers in the tidal Guangzhou segment of the Pearl River estuary, China. Int. Rev. Hydrobiol., 94: 688-705.

Ward, J.V. \& K. Tockner. 2000. Biodiversity: towards a unifying theme for river ecology. Freshwat. Biol. 46: 807-819.

Zsuga, K. 1997. The ecological condition of the Criş/Körös catchment area on the basis of planktonic fauna. In: Sárkány-Kiss, A. \& J. Hamar (Eds), The Criş/Körös Rivers' Valleys. A study of the geography, hydrobiology and ecology of the river system and its environment. Tiscia Monograph Series 2 - Szolnok - Szeged - Târgu Mureş: 135-152. 